\title{
Dialect, language, nation: 50 years on
}

\author{
John E. Joseph ${ }^{1} \cdot$ Gijsbert Rutten ${ }^{2} \cdot$ Rik Vosters $^{3}$
}

Received: 2 May 2020 / Accepted: 2 May 2020 / Published online: 12 May 2020

(c) The Author(s) 2020

\begin{abstract}
Over 50 years ago, the Norwegian-American linguist Einar Haugen published a seminal paper entitled 'Dialect, language and nation' (Am Anthropol 68:922-935, 1966b), in which he expounds his four-step model of standardization, explaining the development from dialect to standard following a process of norm selection, codification, acceptance and elaboration. In this article, we start by discussing the life and work of Einar Haugen, situating him within the history of linguistic thought throughout his career. Next, we zoom in on his standardization framework more specifically, discussing the relevant aspects of his four-box matrix, but also comparing his initial proposals to later influential publications on the subject expanding on his ideas, most notably by Milroy and Milroy (Authority in language. Investigating language prescription and standardisation, Routledge and Kegan Paul, London, 1985) and Joseph (The rise of language standards and standard languages, Frances Pinter, London, 1987b). Finally, we will proceed to give an overview of what we perceive to be major lacunae or shortcomings in Haugen's standardization framework, focusing on specific elements missing, unclear or in need of refinement in one of the four originally defined steps, but also discussing Haugen's fairly restrictive understanding of the directionality of language change, the narrow empirical scope of traditional standardization research, the crucial role played by ideology in the development of a standard variety, and the strong monolingual bias and relative absence of language contact in traditional accounts of standardization.
\end{abstract}

Keywords Einar Haugen · Standardization · Historical sociolinguistics

Gijsbert Rutten

g.j.rutten@hum.leidenuniv.nl

1 Linguistics and English Language, University of Edinburgh, 3 Charles Street, Edinburgh EH8 9AD, UK

2 Leiden University Centre for Linguistics (LUCL), Van Wijkplaats 4, Postbus 9515, 2300 RA Leiden, The Netherlands

3 Centrum voor Linguïstiek, Vrije Universiteit Brussel, Pleinlaan 2, 1050 Brussel, Belgium 


\section{Introduction}

Einar Haugen's lucid paper 'Dialect, language, nation' was first published in the journal American Anthropologist in 1966b. It introduced the well-known four-box matrix with the key concepts selection, codification, acceptance and elaboration. Though Haugen was by no means the only linguist interested in standardization and related sociolinguistic topics at the time (cf. Ferguson 1959; Labov 1963; Kloss 1967), his (1966b) paper has played a crucial role in the development of standardization studies over the past half a century, and keeps inspiring researchers until the present day. Most of Haugen's works were primarily synchronic in nature, with however consistently taking into account the inherent historicity of language. 'Dialect, language, nation', with its focus on the sociolinguistic shift from a dialect to the language of a nation, necessarily had a strong historical accent. What Haugen may not have envisaged in the 1960 s is that out of the then relatively young discipline of sociolinguistics another new discipline would emerge from the 1980s onwards, viz. historical sociolinguistics (Auer et al. 2015). It is particularly within this field that standardization is analyzed as a historical phenomenon, characteristic of postmedieval Europe, and Haugen's approach has been followed closely, most notably in the edited volume by Deumert and Vandenbussche (2003a) that lays bare the sociolinguistic history of the Germanic languages in terms of the Haugen matrix.

This special issue, which emerges from a workshop at the ninth International Conference on Language Variation in Europe (ICLaVE) at the University of Málaga in June 2017, brings together specialists in historical sociolinguistics. They were asked to reflect on one of Haugen's key concepts, paying tribute to his enduring influence, while also discussing possible refinements, corrections, changes or additions emanating from a couple of decades of historical-sociolinguistic research. In this introductory article, we will first zoom in on Haugen himself: first author John Joseph discusses his life and intellectual development, situating Haugen's work within the history of linguistic thought at the time, and reflecting on how his life and education shaped his theories on language and standardization. Next, Gijsbert Rutten and Rik Vosters move on to a brief outline of his influential 1966b theory of standardization, followed by a discussion of some later work by Milroy and Milroy (1985), and Joseph (1987), who expanded the original Haugen model with new and additional dimensions. In the final part of the paper, we conclude by discussing various ways in which the original model can and should be modified, situating and briefly summarizing the contributions of this special issue within this research agenda, or discussing how they aim to fill a notable blind spot in Haugen's work on standardization.

\section{Einar Haugen: life, work and legacy}

Einar Ingvald Haugen (1906-1994) played a pivotal role in the development of linguistics in the middle decades of the twentieth century, where 'pivotal' has both its extended meaning 'of vital importance', and the more literal one of the 
central point where a turning takes place. It was the turn from a linguistics which offered two choices-analyzing language systems, or tracing their historical evolution-toward one embracing a wider range of perspectives, including variation within languages, the place of languages in the lives of the people who speak them, and the role played by certain speakers in determining which variants are regarded as standard/correct/good.

Today these seem like concerns of obvious importance, and indeed in the 1930s their significance was not unrecognized, though they were looked upon as problems for scientific linguists to overcome, rather than as an opportunity for them to make a positive social contribution. This was Haugen's vision, eventually brought to fruition in the 1950s through his sheer Viking-like persistence and determination. He was however a thoroughly American Viking, who, where linguistics was concerned, understood the meaning of 'If you can't beat'em, join'em' - something easier said than done.

His education was in language-and-literature departments, all the way through his master's and doctorate in Scandinavian languages at the University of Illinois, where one of his teachers, George T. Flom (1871-1960), had been a founding member of the Linguistic Society of America in 1924. It was to another languageand-literature department, at the University of Wisconsin, that Haugen was hired after completing his $\mathrm{PhD}$ in 1931. Over the next years he published on linguistic but also historical topics, and on literature, notably Strindberg and Ibsen. In 1932 and 1933 he produced articles on Ivar Aasen (1813-1896) and the reformed Norwegian language which he engineered, usually known as Nynorsk, though Haugen preferred the term Landsmål, appreciating its ambiguity: the language 'of the land' in the senses both of being based on the speech of those who tilled the soil, and of belonging to the land of Norway, rather than to one of the provinces of the Kingdom of Denmark. Linguists were not meant to sully themselves with mere political issues, but Haugen had taken the struggle over the rival forms of Norwegian as the subject of his doctoral thesis.

In preparing his 1934 textbook Beginning Norwegian, Haugen could hardly ignore the language politics. 'The standard of educated speech in the city of Oslo has been followed as closely as possible' (3rd ed, 1952, p. vii) - in effect, classical Dano-Norwegian, as he called the variety known in Norway as Bokmål ('book language') or Riksmål ('official language', sometimes with a distinction made between them such that Riksmål is the more conservative of the two). This was a pioneering textbook in its application of a core principle of linguistics-that the spoken language is the real language, with writing as its secondary representation-at a time when it seemed wildly radical to question the consensus that the goal of university language study was to comprehend the great works of literature in their original versions. Pinning 'the standard of educated speech in the city of Oslo' to its mast allowed Beginning Norwegian to sail a course between the Scylla of being castigated as philistine and unworthy of university credit, and the Charybdis of committing fully to either Bokmål or Landsmål, since their stark differences in print could often be diplomatically blurred in Haugen's phonetic transcriptions of educated Oslo speech. 
In 1938, for his first article in Language, the journal of the Linguistic Society of America, Haugen opted strategically for the historical linguistic route. 'Phonological shifting in American Norwegian' identifies itself more specifically, a few pages in, as a study of 'American Solør', Solør being the district in southeastern Norway from where the family of Haugen's American-born informant had emigrated. ${ }^{1}$ The article is framed as a study that uses contemporary data to elucidate the processes through which languages have influenced one another through migration and conquest. The use of a single informant was not uncommon in the study of American Indian languages, but was an unusual choice for Haugen to make in his representation of 'American Norwegian', especially since he could have made use of his own speech production and intuitions. Twenty years later such introspective data would make a spectacular return with Chomsky, but linguists of the 1930s were wary of it for fear that the analysis would lack the objectivity needed for claiming scientific status.

Using his single informant gave Haugen both objectivity and intense focus, eliminating the variables which multiple informants inevitably present, in order to home in on how the Solør dialect had changed through its bilingual contact with English. Note that it is the dialect's bilingual contact under study-not that of speakers, which could be no more than implicit, lest the article be rejected by Language as belonging to sociology or psychology. Or worse: literary studies, the field which dealt with individual language production, and the one from which linguistics had been struggling for independence since the previous century.

The language-and-literature departments in which Haugen studied and worked were formed in the age of philology, a field with ancient roots which, as Turner (2014) has demonstrated, is the source and origin not just of language study but of the humanities generally. Since the second half of the nineteenth century, when academic life attained more or less its current form, the specialization of academic enquiry has sped up the polarization between what Latour (1991) calls Nature and Subject/Society; but the title of Latour's book is We Have Never Been Modern, because the desired polarization is ultimately unattainable. Whether we aim to make our object of study purely natural or purely social, we always end up somewhere in the space between the poles-the space of hybrids, as Latour calls them. ${ }^{2}$

Mainstream academic linguistics since at least the Neogrammarians in the 1870s has attempted to construct language and languages as natural objects, which come about organically, from the ground up. Enquiry into the origins of human language

\footnotetext{
1 The informant, Odin W. Anderson (1914-2003), a student at the University of Wisconsin, would go on to be a leading figure in medical sociology. Haugen (1953, vol. 1, p. 47) cites a 1930 study by Anne Simley (1891-1992), not mentioned in Haugen (1938), and comments that 'her results check entirely with the writer's observations and have the advantage that they are statistical', being based on 115 children of Norwegian background attending the school in Crookston, Minnesota where Simley taught, and 'coming from fifty widely separated communities [...] It seems safe to say, then, that this study includes the typical speech defects of the American-born Norwegian' (Simley 1930, p. 469). She found that 'Only eleven of these one hundred and fifteen students spoke standard midwestern speech' (ibid., p. 470), which she implicitly identifies in phonological terms.

2 A detailed exploration of these questions can be found in Joseph (in press a).
} 
was excluded from the sphere of science on methodological grounds-conveniently, since questions involved were discomfiting. Also excluded was enquiry into how any particular language came to be regimented into a form sufficiently homogenous as to be described in grammars and dictionaries and textbooks and style guides, because that was a social process that the structural linguists had no language in which to describe and analyze. They could only talk about it in terms of what Latour calls Subjects-Dante's Italian, Caxton's English, Ibsen's Norwegian-the terms they themselves had rejected as incompatible with science.

What a few brave souls strove to do was to create a language of analysis for the social dimension of language stratification and standardization that structural linguists could hear. Otto Jespersen (1860-1943) had attempted it back in 1925 , but others did not take up his initiative. ${ }^{3}$ The Prague School structuralists devoted great energy to it in the 1930s (Havránek 1932; Mukařovský 1932), but in terms of 'literary language', hence not hearable to linguists. In Russia, Mikhail Bakhtin (1895-1975) too was pursuing these questions in a literary context (1981 [1934-1935]), until he was silenced for political reasons. The key was to create a discourse sufficiently formalized and formulaic to be hearable to linguists, which meant talking about language as a linguist, from a position within the field of hybrids that did not get so close to the Subject/Society end that mainstream linguists would cease to hear, because it threatened the hard-won scientific status which they believed was tied to the Nature end.

What Haugen perceived was that striving to purify the polarization meant that much of the reality of language was ignored, because it lay within the shunned realm of hybrids. For him, hybridity was the story of his life. As a Norwegian-English bilingual, born and raised in Sioux City, Iowa, Haugen was more American than Norwegian, but still a hyphenated American. He grew up speaking a non-standard English and a non-standard Norwegian, in what he described as 'the bilingualism that was forced upon me in childhood' (Haugen 1980, p. 133). It was 'a challenge', he said; but his 'struggles in overcoming it' are what turned him into a linguist (ibid., p. 134). He admitted it was 'ironic that after advocating bilingualism for so long, I should refer to it as a handicap' (ibid.), and indeed ironic seems an understatement.

But then, studying Norwegian, Haugen could not escape the fact that the language was itself bilingual, or as he would later term it, 'schizoglossic' (Haugen 1962). If he savored the double meaning of Landsmål, perhaps the term Dano-Norwegian appealed to him because it wore its hybridity on its sleeve. Landsmål too, though created in an attempt at purification, lay squarely in hybrid land. Each variety had its particular prestige. Using Dano-Norwegian marked one as belonging to the educated middle class rather than the working class. Landsmål too was a mark of the educated middle class, but of that rarefied strata which turned its back on vulgar, imported bourgeois values in favor of (an admittedly Romanticized) national identity.

\footnotetext{
3 At least not immediately: Haugen (1980, p. 135) recalled that Jespersen's books 'opened the whole range of linguistic inquiry to me. His pragmatic, eclectic, undogmatic views of language made him my hero, and it was a proud moment in 1935 at a linguistic congress in Copenhagen, when I could walk up to him, shake his hand and tell him so'.
} 
With English, the young Haugen again experienced a sort of internal bilingualism, less politically charged but with the personal stakes just as high. His 'struggles in overcoming' bilingualism had less to do with his Anglicized Norwegian than with its traces in his English, which presented a hurdle to overcome in his education and his social relations beyond Sioux City's Norwegian-American community. It was not 'proper' English, and when he said or wrote something non-standard it would draw a reprimand from his teachers, who, although they knew non-standard English when they heard or saw it, could never quite articulate what exactly Standard English was. All right, I have to confess that this last sentence projects onto Haugen the experience of another small-town midwestern American boy born 50 years after him; my excuse is the understanding that this affords me of his work. While our experiences had much in common, he belonged to the generation of my grandparents, when most people born in the USA still spoke English with features of the languages of their immigrant forebears, even if their own knowledge of those languages was weak. Haugen's struggles in school which came from not having Standard English as his home language were of a similar nature to mine, but greater. I at least had exposure to it through radio and television, he only through books.

His work of the 1930s on the effects of bilingualism on language structure expanded through the 1940s, culminating in his two articles of 1950 which began the modern discourse on societal bilingualism. Appropriately, one appeared in a European journal, Lingua, the other in an American journal, Language. 'Problems of bilingualism', in Lingua (Haugen 1950a), put the word in its title. 'The analysis of linguistic borrowing', in Language (Haugen 1950b), opens with the word 'Bilingualism'. The fact that this article was also Haugen's Presidential Address to the Linguistic Society of America makes his bravery all the more impressive: he was willing to risk his reputation in this high-profile context in order to promote the sort of linguistics he believed in, and that his audience was neglecting, rather than take the comfortable route of a paper that would praise what they were doing and cement his position as their leader. He preferred the role of Socratic gadfly.

There was, meanwhile, a similarly-spirited project to his developing at Columbia University in New York, led by André Martinet (1908-1999). ${ }^{4}$ One student of Martinet's in particular, Uriel Weinreich (1926-1967), devoted his 1951 doctoral thesis to 'languages in contact', 5 giving due attention to Haugen's work while also raising serious questions about the implications of bilingualism, social stratification and standardization for the idealized language systems which hard-core linguists continued to regard as the only viable object of scientific enquiry (Weinreich 1954). By the

\footnotetext{
${ }^{4}$ Martinet had left France at the end of WWII under a cloud of accusations of Nazi collaboration (see Joseph 2016). He resumed his university career in France in 1955. Meanwhile, in Germany, Heinz Kloss (1904-1987), who had been an active Nazi Party member given responsibility for planning language policy in English-speaking lands following German victory in the War (see Hutton 1999), had produced a study of the historical development of language status (Kloss 1952) which would feed significantly into enquiry into language standardization in the 1960s.

5 This was the title of the abridged version published as Weinreich (1953), with the full thesis eventually appearing as Weinreich (2011). See also Haugen (1954), and the discussion of it in Joseph (in press b).
} 
mid-1950s, the sort of research that Haugen had pioneered two decades earlier was entrenched, though never more than in a marginal position.

This historical overview has been necessary to counteract a tendency to treat Haugen's work relating to standardization as having begun in the 1960s, when in fact his output of that decade is continuous with what he had been doing at least since his articles on Aasen of the early 1930s. This takes nothing away from the originality or importance of his Language Conflict and Language Planning (1966a), 'Dialect, language, nation' (1966b) or other publications which receive detailed examination and discussion in the papers that follow in this special issue. Quite the contrary: it helps to us to situate and understand aspects of Haugen's model of the language standardization process which have been criticized for appearing too 'structural', hence reductionist and limiting, as if Haugen were blind to the full complexity of how a standard language comes into being and is spread, maintained and altered.

Wendy Ayres-Bennett is right to say that the appeal of Haugen's model lay not least in its clarity and simplicity. Yet each of the papers in this special issue is framed as an expansion of the model. That is, if not inevitable, at least typical of how academic fields progress; and based on my interactions with Haugen in the 1970s and 1980s I doubt that he would have wanted it otherwise. ${ }^{6}$ He would be delighted to know that he has been neither forgotten nor slavishly followed, but that the research agenda he did so much to establish is being pushed forward and heard more than it was 50 years ago, though certainly not yet by the mainstream. If there even is a mainstream: perhaps, like a great river, linguistics has split into many rivulets that can never rejoin. That is good insofar as it allows us freedom to pursue our varied research agendas, but lamentable when it licenses not merely our inability to hear what each of us is saying, but to interpret that as a sort of progress.

The autobiographical dimension in Haugen's work is more significant than has been realized. He certainly provided ample clues, from the dedication of The Norwegian Language in America to his parents for introducing him to 'the pleasures and problems of bilingualism' (Haugen 1953, vol. 1, p. v), which sounds rather backhanded on a personal level, to the 1980 'On the making of a linguist', where he makes clear that those problems are what shaped his career. When he sat down to analyze how the forms of a language move, or rather are moved, from the dialectal margins to the center that a standard language represents, it would have taken an extraordinary power of dissociation not to conceive of this in terms of the experience of the boy from Sioux City, Iowa, who had to move, or be moved, from the Norwegian of his home, which was not 'real' Norwegian, to the English of his school, via a 'Norwenglish' that was not standard. And again, later, to the Norwegian of a Norway sharply divided over what 'real' Norwegian should be. Schizoglossia, indeed. And then, finding himself among linguists unable to hear any of this, he had to learn how to conform his treatment of the issues to a metalanguage

\footnotetext{
${ }^{6}$ I first met Haugen when he spoke on 'Language problems in Scandinavia' at the University of Michigan on 27 March 1978, and will always be grateful for his encouragement regarding my planned doctoral thesis on language standardization (Joseph 1981), when nearly every other linguist I told about it reacted with alarm.
} 
they considered professionally legitimate within their attempted purification of their field to its Nature pole, on which they believed its scientific status depended.

Each of these was a step in the linguistic standardization of Einar Haugen. Only thus could he say what he had always wanted to say, and get a hearing, albeit a limited one, from the scientific community to which he initially did not sound structuralist enough. Then, a few decades later, he sounded too structuralist. The limits to which he had long ago had to conform changed from a strength to a weakness, whereupon his work received the equivalent of an old Norse ship burial. It now reaches the next stage of the journey: rediscovery, resuscitation, and a reboot in which we make him-no, allow him to-conform to our present-day intellectual values. For an old warrior like Haugen, that has to beat oblivion. We salute your return from Valhalla, mighty Einar.

\section{Haugen's four-box matrix}

The seminal paper 'Dialect, language, nation' is Haugen's most well-known work on standardization. In this paper, he introduces selection, codification, acceptance and elaboration as the four crucial concepts needed to describe the historical process of standardization, or as Haugen (1966b, p. 933) himself put it: '[t]he four aspects of language development that we have now isolated as crucial features in taking the step from "dialect" to "language", from vernacular to standard'. Just like Kloss $(1952,1967)$ slightly before him, Haugen started from the dialect-language conundrum, and taking a mostly functional approach to the topic, he tried to build on Ferguson's (1962) work into 'the path that 'underdeveloped' languages must take to become adequate instruments for a modern nation' (Haugen 1966b, p. 931). When we say the paper introduces the four key terms, we actually mean that it rounds off a largely theoretical discussion by offering the following four-box matrix:

\begin{tabular}{lll}
\hline & Form & Function \\
\hline Society & Selection & Acceptance \\
Language & Codification & Elaboration \\
\hline
\end{tabular}

Most essential to Haugen are codification of form and elaboration of function. Codification consists in 'developing the forms of a language, i.e. its linguistic structure, including phonology, grammar and lexicon' (Haugen 1966b, p. 931), in line with what Ferguson (1962) more generally equated with standardization as a whole: developing and registering norms for the form of a language. This is now often also subsumed under corpus planning. Codification serves to move towards the ideal goal of a standard language as possessing 'minimal variation in form' (Haugen 1966b, p. 931). On the functional side, however, Haugen talked about elaboration, which he equated with Kloss' Ausbau concept. Haugen focused mainly on the use of a written standard in prestige functions such as in the technical and scientific domains, and elaboration thus contributes to the ideal of 'maximal variation in function' (Haugen 1966b, p. 931). Taking these two together gives us Haugen's basic definition of a 
standard language, as being a variety possessing 'minimal variation in form' and 'maximal variation in function' (Haugen 1966b, p. 931).

Still adding to the form dimension, however, is also the step of selection of norm, that is, selection of a basis from which standard language norms can be derived. Haugen seems to see this step as a precursor to codification, and presents selection as a fairly top-down process. He mentioned that ' $[\mathrm{t}] \mathrm{o}$ choose any one vernacular as a norm means to favor the group of people speaking that variety. It gives them prestige as norm-bearers and a head start in the race for power and position', although he also acknowledged the possibility of 'a recognized élite [which] already exists with a characteristic vernacular, [in which case] its norm will almost inevitably prevail' (Haugen 1966b, p. 932).

A final aspect of standardization is again primarily related to function: acceptance by the community. Haugen pointed out that, 'a standard language, if it is not to be dismissed as dead, must have a body of users', even if just a 'small but influential group' of language users within a community (Haugen 1966b, p. 933). A few years later in the paper 'Language planning, theory and practice', Haugen (1972) replaced acceptance with propagation in order to have an active rather than a passive 'procedure', so a term more in line with the other three terms. This was also in accordance with his aim to not only describe the history of standardization, but to also devise a model for future language planning activities. Haugen was explicitly also oriented to contemporary practical language planning - i.e. how to standardize a language, how to develop a vernacular so that it becomes a language-but the $1966 \mathrm{~b}$ paper entailed a historical analysis of how, in the past, vernaculars had developed into standard languages. Still a few years later, Haugen (1987, pp. 59-64) again reevaluated his model and adopted implementation as the fourth term. He defined implementation as 'the activity of a writer, an institution, or a government in adopting and attempting to spread the language form that has been selected and codified', thereby stressing that 'the spread of schooling to entire populations in modern times has made the implementation of norms a major educational issue' (Haugen 1987, p. 61). Implementation thus resembles acquisition planning (Cooper 1989; Hornberger 2006), i.e. the often governmental efforts at spreading the standard variety among speakers.

\section{Extending the matrix}

About as well-known as Haugen's seminal 1966b paper is the 1985 book by James and Lesley Milroy. Although they work largely within the Haugen framework, their general approach to issues of standardization differs significantly from Haugen in various respects. From the formal perspective, the Milroys are strongly concerned with the importance of uniformity in standardization, also expressed in the phrase 'minimal variation in form', less so with the functional side of elaboration ('maximal variation in function'). At the same time, their description of uniformity as the main goal of standardization, which results from 'intolerance of optional variability in language' (Milroy and Milroy 1985, p. 26), reveals what they add to the Haugen model, viz. an emphasis on the language attitudes that 
lie at the heart of efforts at standardization. In fact, a major contribution by the Milroys lies in their description of standardization as an ideology. In their view, standardization is a policing activity resulting from a negative attitude towards the inherent variability of language. In later publications, James Milroy (2001) elaborated on the standard language ideology, on its role in history, as well as on its role in historical-linguistic and sociolinguistic analyses of variation and change.

The Milroys also add three key concepts to the original four, viz. diffusion, maintenance and prescription. In their view, it is not sufficient for a variety to be selected as the standard, and to be accepted by an often small part of the language community. The standard also needs to be disseminated through the community, both socially and geographically. Such diffusion can be reached by various means. In European history, for example, the printing press and the educational system have been crucial. Maintenance ties in with elaboration as it refers to the continued efforts to keep the standard in its privileged position, viz. as the variety fulfilling as many functions in society as possible. Prescription is the increasingly strong focus on correctness as exemplified, for example, in prescriptive teaching practices in schools. It typically follows codification.

Like the Milroys, Joseph (1987) worked within the Haugen model while also adding significantly to its refinement. An important distinction discussed by Joseph is that between language standards and standard languages, that is, between processes such as convergence and focusing that can be found in language communities across the globe and throughout the centuries, and the particular drive towards linguistic uniformity in post-medieval Europe that often also involves explicit codification, institutional and/or political support, and nationbuilding. The distinction reminds us that not all cases of formal uniformization should be treated as instances of standardization, and that the societal perspective, including acceptance, implementation and ideology, is as important as the linguistic perspective.

Another valuable distinction introduced by Joseph (1987, p. 60) concerns the difference between circumstantial and engineered standardization. Haugen (1966b) assumes a fairly top-down approach to standardization: selection is typically executed by a privileged group of people, codification also occurs on their behalf, and acceptance, as Haugen acknowledges, often only happens among these same groups of people. The Milroys implicitly continue this approach when they consider standardization to be an ideology. This is what Joseph calls engineered standardization: a group of standardizers consciously advocates the use of a particular variety, and is engaged in the selection, codification, elaboration and implementation of this variety. Joseph (1987), however, points out that selection can also be a by-product of other events, i.e. it can be circumstantial. A particular variety can gradually emerge as the conventional form for specific purposes, such as producing literary, legal or religious prose, or become the dominant variety by virtue of broader sociohistorical developments. A side effect may be that this variety also develops into the standard form. Importantly, none of the language users involved may initially have been striving for this to happen. 


\section{Lacunae, additions and elaborations of the model}

In the remainder of this article, we will discuss a number of lacunae in Haugen's approach that have become evident after decades of sociolinguistic and historicalsociolinguistic research, and to the solution of which the articles in this special issue aim to contribute. The main question that we asked the contributors to this special issue was to identify possible additions to and elaborations of the original model. Some contributors, whose papers are briefly summarized and discussed below, chose to focus on an existing dimension of the original model, elaborating the concepts of selection, codification and implementation or acceptance. Other papers, the discussion of which will be integrated in the following sections, chose to focus on elements or dimensions completely lacking in Haugen's original propositions.

Building on the original model, the contribution by Simon Pickl in this special issue, entitled 'Factors of selection, standard universals, and the standardisation of German relativisers', problematizes easy dichotomies concerning the selection process. He builds on the distinction between macro-level selection of a variety and micro-level selection of specific variants (cf. van der Wal 2007), and links this to Deumert and Vandenbussche's (2003b) likewise important distinction between monocentric selection (with a standard mostly based on one existing variety) versus polycentric selection (including variants from different dialects and dialect areas) which was already present in Haugen's (1982) work as what he labelled the unitary versus the compositional thesis. Pickl points out that combinations of both micro and macro selection often occur, and even gradations in between both are possible. By drawing attention to the fact that it is often not individual linguistic features but rather larger groups of co-occurring and coherent variants that make up specific varieties, he introduces the term meso-selection to indicate that, also in standardization, we often need to deal with sets of co-occurring features being selected-or not-into the standard variety, instead of just treating variants as independent and in isolation of the broader (socio)linguistic space in which they operate. At the level of micro selection, he then goes on to consider different structural, distributional and attitudinal factors driving the selection process from a linguistic point of view-distinguishing these selection factors from selection criteria, which refer to the motivations underlying the metalinguistic choice for one variant over another in the ensuing codification process (cf. Davies and Langer 2006.). This leads to a reflection on the concept of 'standard universals' (De Vogelaer and Seiler 2012), to be found in standard languages across the globe, as a result of shared variant selection principles underlying the standardization process. This is then turned into an empirical investigation by focusing on relative pronouns, taken to be a hallmark of written standard languages in a European context. Pickl examines the shift in German between the seventeenth and the twentieth century, from older so and welch-relativizers to modern standard $d$-relativizers. Considering the role of different selection factors in the process, he concludes that multiple causation is at the heart of the selection process: structural, distributional and attitudinal factors all intertwine over time, but often also lead to the selection of similar variants across (standard) languages. 
Two of the contributions in the special issue deal with the codification stage, albeit in very different ways. Wendy Ayres-Bennett departs from Haugen's original (1966b) and later definitions of codification, remarking the absence of a coherent view of prescription in relation to codification-in fact, she shows that for Haugen, both terms are interchangeable, although the later work by Milroy and Milroy (1985) does consider the prescription stage as a separate addition to the model. Based on previous work, Ayres-Bennett discusses the relationship of codification to both descriptive and prescriptive views of language, and proposes a typology of different types of prescriptivism, forcing us to adopt a nuanced and fine-grained view on prescriptivism, especially in relationship to actual usage (e.g. differentiating between prescriptive effects as a direct result of a text, or as a result of later perceptions of a text, as is the case with many supposedly hallmark prescriptivist works.) Another key concept, Ayres-Bennett argues, related to both codification and prescription, is purism, which is lacking from both Haugen's original model as from the later extensions by the Milroys. Following the fairly broad definition of Thomas (1991), which not only includes the desire to rid a language of 'foreign' elements, but is oriented towards resisting a wider range of undesirable or 'contaminating' elements, also here she discusses different types of purism, and reflects on how these relate to the similar but not identical issues of prescription and codification more broadly. By triangulating description, prescription and purism, she arrives at a refinement of the codification stage in Haugen's model, which Ayres-Bennett then applies to a supposed champion of French prescriptivism, Claude Favre de Vaugelas (1585-1650). By carefully weighting metalinguistic commentaries and by comparing his observations to contemporary usage, following the suggestions for assessing purism by Thomas (1991), the author concludes that Vaugelas' work is much less of an 'icon' of prescriptivism than is often presumed.

In addition to the more 'Haugensian' view of codification as a process in which shared language norms are explicitly agreed upon and set down in grammars, dictionaries and other, similar reference works, Raymond Hickey, in his article entitled 'Re-examining codification', zooms in on a related element, which he calls 'implicit codification'. Whereas 'explicit' codification refers to traditional situations of topdown standardization efforts, implicit forms of codification occur when there is an unconscious and unspoken agreement within a speech community upon which norms to adopt as part of the standard variety. As such, it is more closely linked to supraregionalization (Hickey 2013) rather than standardization processes, and typical for syntactic as well as phonological features. Hickey discusses different aspects of the concept: he focuses on implicitly codified varieties such as Standard Irish English and Standard Scottish English to illustrate the workings of implicit codification, but provides further examples from a wide range of different contexts as evidence of the implicit move in the direction of the ideal of 'minimal variation in form' (Haugen 1966b, p. 931).

The final paper which focuses explicitly on one of the four dimensions of Haugen's matrix, is the contribution by Gijsbert Rutten, Andreas Krogull and Bob Schoemaker, entitled 'Implementation and acceptance of national language policy: the case of Dutch (1750-1850)'. They focus on the implementation or acceptance stage. Departing from a case study of the Netherlands around the beginning of the 
nineteenth century, where a national language policy was established and an official grammar and orthography were designed for use in the national school system, they argue implementation and acceptance are crucial in the standardization process: propagating standard language norms and making sure they are disseminated and indeed accepted by a wide range of societal actors, is not only the 'Achilles heel' (Deumert and Vandenbussche 2003b, p. 7) for the historical standardizers involved in the enterprise, but also of previous research into standardization. They hold that little empirical work has focused on this aspect of standardization, but with their case study clearly demonstrate how the study of implementation or acceptance can indeed be operationalized in an empirical and sociolinguistically informed research design. On the one hand, they focus on the educational domain, investigating orthographical practices and prescriptions in schoolbooks and other teaching material, to gauge the extent to which the national policy made its way down to everyday teaching practices, and on the other hand, they juxtapose this with a more macro-level corpus-based investigation of language use in various text types, before and after the new policy took effect. Surprisingly, they find that in the case of the Dutch orthography, top-down implementation of the new norms was fairly successful, and so this fascinating example of large-scale language and language-in-education policy at the turn of the nineteenth century can indeed be characterized as an early yet successful experiment linking language and nation.

\section{Directionality of standardization}

A next cluster of topics which we feel are underrepresented in Haugen's original work, extending beyond the scope of the four-box matrix, ties in with the aforementioned difference between engineered and circumstantial standardization (Joseph 1987), and can be summarized as the question of the directionality of standardization. Working within a language planning approach, Haugen adopted a top-down view of standardization: selection, codification and functional elaboration are normally the responsibility of a privileged elite, who subsequently try to implement the standard across the language community, aiming at its acceptance. This may in fact be the most common view of standardization, present also in many chapters in Deumert and Vandenbussche (2003a), and theoretically elaborated in Ammon (1995, p. 80). Ammon (1995) distinguishes between the majority of the population on the one hand, and on the other hand the codex and the codifiers, norm authorities (such as teachers), model speakers and writers (such as literary authors and their texts), and professional language experts (such as linguists). The directionality implies that the majority orients to the standard promoted, demonstrated and discussed by the other participants. Milroy (1992) criticizes such prestige-based conceptualizations of the sociolinguistic space, arguing that the actual choices made by language users may very well diverge from the perceived standard, and instead converge to their local networks. More recent theorizing in sociolinguistics introduces the indexical field instead of a hierarchically organized sociolinguistic spectrum with the prestigious standard at the top (Eckert 2008). So even if standardization is a 
top-down phenomenon, language users are not at all expected anymore, theoretically nor empirically, to model their behavior after normative pressures from above.

Such top-down, engineered standardization 'from above' (cf. Rutten and Vosters in press) contrasts with standardization 'from below' (cf. Elspaß in press). While modern sociolinguistics criticizes the simplified view of a hierarchically organized sociolinguistic space, emphasizing the importance of flexible identities, styles and style-shifting in changing contexts, historical sociolinguistics has shown that standardization can also be the result of wholly different processes than top-down normative pressure. Mobility and increasing contact may lead to convergence or koineization. Medieval Spain is a case in point, where focusing occurred as a result of contact, not as a case of standardization (Tuten 2003). Supralocal norms for writing, sometimes also for speech, may emerge, as for example in England (Nevalainen and Tieken-Boon van Ostade 2006). Such focused varieties, developed in (late) medieval Europe, subsequently impacted the standardization of these languages, but they themselves were not the result of a top-down standardization process. Also in postmedieval Europe, standardization can be the outcome of other societal forces than envisaged in Haugen (1966b). Voeste (2007) argues that orthographic convergence in the German language area in the sixteenth century was not so much the result of ongoing selection and codification in metalinguistic discourse, but of technical innovations related to printing instead.

Standardization can take many directions, and conventionalized forms may spread from below to above as well as the other way around. Top-down interference with language can certainly be found in historical contexts, though it remains to be seen to what extent language users felt the need to comply with superimposed norms. Effectiveness is therefore an issue relevant to standardization as a top-down phenomenon. Framing standardization in terms of conscious language planning raises the question of the success of such planning initiatives. If selection, codification and elaboration are often restricted to privileged social circles, then a crucial issue is how this socially restricted variety gets disseminated to larger groups within society. Implementation and acceptance should therefore be at the heart of standardization studies. It is obvious, however, that a lot of archival and corpus work is needed in order to establish the social success of a standard variety. Such empirical innovations characterize historical sociolinguistics.

\section{Empirical innovations}

One of the major contributions by historical sociolinguistics over the past decades is certainly the construction of large scale historical corpora with language data diverging from those traditionally used in historical linguistics in a number of respects (Elspaß 2007). Often, the data sets used in historical linguistics comprise specific registers such as literary and religious prose, which are moreover produced by small numbers of people with similar social profiles (male, wealthy, well-educated), living in similar spaces such as the capital or close to it (e.g. the wider London or Paris region). Historical sociolinguists have compiled corpora with texts that are closer to the experiences of historical social actors, and arguably also closer to the historically 
spoken language, such as private letters and diaries (Nevalainen and RaumolinBrunberg 2017; Elspaß 2005; Rutten and van der Wal 2014; Martineau 2013). Ideally, these texts represent larger groups of society, including women, less-privileged people, and language from other regions than the capital area. Careful inspection of such representative corpora enables researchers to reconstruct the sociolinguistic trajectory of standardized forms, and to see whether they were picked up by specific groups of language users and/or used in specific registers.

The contribution by Elspaß in this special issue, entitled 'Alternative sources of data for alternative histories of standardisation', explores such topics by focusing on the role played by hand-written texts in standardization history. While formal, written texts are most typically associated with the standardization process, certainly also in the work of Haugen, Elspaß draws our attention to the fact that mass literacy from the nineteenth century onwards, as a crucial step in the standardization process, was achieved by most people learning to write (and read) handwritten texts. Such handwritten texts by less educated writers, often letters, diaries or other egodocuments 'from below', can be seen as the 'roots' of Western European written culture, but were necessarily hybrid in nature (cf. Puttaert 2016): on the one hand, they served as instruments to spread codified norms, but on the other hand, they also operated as transmitters of regional norms of usage. By discussing three examples of such norms of usage in a corpus of letters written by German emigrants to North America in the nineteenth century, Elspaß shows how elements which are part of the High German standard nowadays were completely invisible in printed texts of the long nineteenth century, but can be found in sources from below. He sets out a research agenda which aims to trace the trajectories of such variants silently contributing to the standardization process, by shifting the exclusive focus in traditional language history away from corpora of formal, printed and literary texts, to also include more oral, informal and handwritten text types as alternative sources of data for standardization history.

Interestingly, such corpora with a focus on texts from below also allow analyses of unsuccessful cases of standardization. So-called failed standardizations have long attracted the attention of historical sociolinguists, well-known cases being Scots (Dossena 2003, McColl Millar 2005, pp. 89-91) and Low German (Langer 2003). Both 'failures' have largely been attributed to social and political circumstances, in particular the increasing importance of closely related varieties such as English and High German, which halted the incipient standardization of Scots and Low German. At the level of particular linguistic forms, large corpora make it possible to trace their gradual disappearance from the written language, that is, their de-selection (or non-selection) for the standard variety. Analyses of deselection should be accompanied by the study of metalanguage, in which stigmatization may occur, as in the case of the auxiliary tun 'do' in the history of German (Langer 2001). In recent years, the gradual disappearance from writing of forms commonly used in the spoken language, often until the present day, has been termed invisibilization (Langer and Havinga 2015). The term reflects the more or less conscious removal of certain forms from the written tradition, limiting their use to (informal) spoken registers (cf. the concept of erasure, discussed by Irvine and Gal 2000). As with selection, the concepts of deselection and invisibilization call for detailed studies of effectiveness. 
Introducing corpus linguistics into standardization studies, and shifting attention to the actual adoption, or non-adoption, of certain forms does not imply a reduced interest in metalanguage. Traditionally, metalanguage is at the heart of studies that focus on selection and codification, but the empirical base of historical sociolinguistics also comprises collections of metalinguistic publications. This has also led to an interest in the inherent variability of the genre. Often, metalinguistic traditions are not as homogeneous as suggested by a linear focus on selection and codification. In fact, the variation found in metalinguistic texts can be of great help in reconstructing the sociolinguistic value of historical language forms (Ayres-Bennett 2004; Poplack et al. 2015).

Often, the larger and more diverse databases used in historical sociolinguistics provide new perspectives on old problems: forms thought to be deselected at first, turn out to be still used at a later stage (multiple negation is a case in point in various languages, cf. Nevalainen and Rutten 2012); forms thought to be recent innovations turn out to occur already in informal writing in earlier stages of the language (e.g. paratactic weil 'because' in German, or ne-less negation in French); and forms thought to be stigmatized and deselected continue to be used in informal writing (such as wegen 'because of' + dative or accusative case, or (als) wie as the comparative marker in German, cf. Elspaß 2014). In many cases, this means that the supposed standardization of particular forms is debatable or restricted to certain registers and/or social groups, or in any case represents a more recent phenomenon than previously thought. Here, historical sociolinguistics connects with recent research on destandardization and demotization (Coupland and Kristiansen 2011). Paratactic weil, for example, is often seen as a recent innovation indicating changing standard language norms. But if it was a common feature in informal nineteenth-century writing, recent occurrences can also be interpreted as the continued use of a long existing form in an increasing number of texts. One generalization is that the written language of the Early and Late Modern periods is far less standardized than traditionally thought, and that for this reason these periods cannot be interpreted in terms of standard-dialect diglossia, and signal a diaglossic repertoire instead (Elspaß 2007; Rutten 2016).

\section{Ideology}

A third element that we wish to discuss here is ideology. Much of Haugen's work predates the growing interest in language ideologies since the 1990s. Deumert and Vandenbussche (2003c, pp. 461-463) indicate that the ideology underpinning standardization, and the social and discursive practices involved in it, are among the research desiderata for standardization studies. Of course, Haugen has nation in the title of his famous paper, but the national context, though historicized and not taken for granted as such, nevertheless seems to function as the natural habitat of standard languages (e.g. Haugen 1966b, pp. 928,930 ). The association of language (not dialect) and nation is not critically analyzed as a metalinguistic phenomenon with pervasive social consequences, but rather as the normal evolution of western societies in post-medieval times. 
Classic analyses such as Lippi-Green's (2012 [1997]) study of the standard language ideology in the United States, Blommaert and Verschueren's (1998) paper on the role of language in nationalist ideologies, and Milroy's (2001) work on the effects of standard language ideology in the history of English as well as in the writing of the history of English have contributed to the deconstruction of standardization and standard languages as sociolinguistic phenomena that need to be tied to particular groups of language users, with particular interests, and interpreted against the background of shifting power relations in historical and contemporary societies. Such deconstruction also involves carefully locating the standard language ideology in its historical time and place of origin, that is, as an essentially eighteenth-century European phenomenon.

Haugen's own work, of course, is not free from ideology either, and José del Valle, in his contribution entitled 'Language planning and its discontents: lines of flight in Haugen's view of the politics of standardization', delves into the glottopolitical underpinnings of Haugen's theory of standardization and language planning. Moving beyond the 'technical-descriptive' tier of the four-step model, Del Valle examines at a historical and sociopolitical level how Haugen connects language planning, standardization and politics, particularly regarding the nation. We learn how Haugen's work is deeply indebted to a modernist perspective on liberal democracy, placing the emergent nation-state center-stage in his view of language and language planning, and subscribing to a view that thinks of standardization as a top-down instrument at the service of equality, offering all citizens equal access to participation in liberal society. Nonetheless, Del Valle also argues that Haugen's work is more ambiguous than a superficial reading might lead us to believe, and after (re)reading his work 'against the grain', the author identities a number of 'lines of flight', internal tensions or inherent ambiguities, which allow for a more nuanced reading of Haugen's texts, for instance regarding his view of language as inherently normative, or regarding the limitations of standardization as an equalizing force. Thus weighing different aspects of his work, Del Valle concludes that 'it is high time to return to Haugen in order to get over Haugen'.

Based on the observation that standardization is characteristic of the age of nationalism, from the late eighteenth well into the twentieth century, one should be careful not to conclude that it is a predominantly western phenomenon. Standardization is, in fact, a global phenomenon, affecting languages to different degrees across societies and across the world. One cannot blame Haugen for focusing primarily on western languages such as Norwegian and English, but sociolinguistic theorizing is certainly more strongly informed by western, that is European and North-American language situations than by non-western contexts (Smakman 2015). In this special issue, too, the languages discussed comprise usual suspects such as the major standard languages English, French, Dutch and German. Darquennes and Vandenbussche (2015) and Lane et al. (2018) are welcome exceptions focusing on the standardization of European minority languages, although studies on standardization outside of a European context are even more rare (cf. nonetheless the contributions in Ayres-Bennett and Bellamy in press). 


\section{Language contact and 'comparative standardology'}

In spite of Haugen's own 'struggles' with bilingualism, a fourth and final dimension which we believe is conspicuously absent from Haugen's work on standardization is language contact (cf. also Deumert and Vandenbussche 2003c, pp. 455-457). In line with his modernist view on language and the nation-state (cf. Del Valle, this issue), and adopting the national community as the more or less natural environment of the change from dialect to language, Haugen hardly pays any attention to multilingual societies, or to the consequences of societal multilingualism and language contact for the standardization process. With his focus on the dialectal origins of standard languages, so-called multidialectism or internal multilingualism is of course implied in the theory, although competing supraregional forces are not explicitly thematized. Here, too, power relations determine the course of the standard and its directionality, from centers to peripheries, but possibly also the other way around. Joseph (1987), in this respect, speaks about the synecdochic move by which one particular dialect changes into the language of a wider, multidialectal community. Such moves usually imply status loss of the non-heightened varieties. Moreover, most European nation-states are in fact multilingual so that the promotion of one variety to the status of standard language often also implies the demotization (and subsequent 'invisibilization', cf. Langer and Havinga 2015) of these minoritized languages.

In spite of the strong monolingual bias, which stands at the core of most language histories, even of languages which have developed in intense contact situations, Haugen does address case studies and examples from a range of different contexts, effortlessly taking his reader from Ancient Greece to Revolutionary France, and on to nineteenth-century Finland. This lines up with a call for more comparative sociolinguistic work on standardization, which can already be found in Joseph (1987). Of course, collections such as Deumert and Vandenbussche (2003a), Darquennes and Vandenbussche (2015), and Lane et al. (2017) set out to do exactly that, and precisely bringing together sometimes very different case studies and comparing them across a common framework such as Haugen's fourbox matrix offers us valuable insights into the factors driving selection, codification, acceptance and elaboration. Nonetheless, the overview articles per language in these collections are still fairly general, and in addition to such macro-level comparisons across languages, we believe that a lot is also to be gained from smaller-scale comparisons of much more specific elements or concepts. We can find a solid basis for such a comparative approach in the article by Pickl in this issue, who departs from the concept of 'standard language universals' to argue that factors underlying the selection process in standardization are often shared across languages, leading to similar standardization outcomes cross-linguistically. In line with our earlier pleas for more comparative and crosslinguistic work in historical sociolinguistics (e.g. Rutten and Vosters 2020, pp. 101-102), we believe this provides a still highly fruitful and promising avenue for future research. 
Open Access This article is licensed under a Creative Commons Attribution 4.0 International License, which permits use, sharing, adaptation, distribution and reproduction in any medium or format, as long as you give appropriate credit to the original author(s) and the source, provide a link to the Creative Commons licence, and indicate if changes were made. The images or other third party material in this article are included in the article's Creative Commons licence, unless indicated otherwise in a credit line to the material. If material is not included in the article's Creative Commons licence and your intended use is not permitted by statutory regulation or exceeds the permitted use, you will need to obtain permission directly from the copyright holder. To view a copy of this licence, visit http://creativecommons.org/licen ses/by/4.0/.

\section{References}

Ammon, U. (1995). Die deutsche Sprache in Deutschland, Österreich und der Schweiz. Das Problem der nationalen Varietäten. Berlin: De Gruyter.

Auer, A., Peersman, C., Pickl, S., Rutten, G., \& Vosters, R. (2015). Historical sociolinguistics: The field and its future. Journal of Historical Sociolinguistics, 1(1), 1-12.

Ayres-Bennett, W. (2004). Sociolinguistic variation in seventeenth-century France. Methodology and case studies. Cambridge: Cambridge University Press.

Ayres-Bennett, W. \& Bellamy, J. (Eds.), Handbook of standardization and standard languages. Cambridge: Cambridge University Press.

Bakhtin, M. M. (1981 [1934-1935]). The dialogic imagination. Four essays. (Ed. \& trans. by Caryl Emerson \& Michael Holquist). Austin: University of Texas Press.

Blommaert, J., \& Verschueren, J. (1998). The role of language in European nationalist ideologies. In B. B. Schieffelin, K. A. Woolard, \& P. V. Kroskrity (Eds.), Language ideologies. Practice and theory (pp. 189-210). New York: Oxford University Press.

Cooper, R. L. (1989). Language planning and social change. Cambridge: Cambridge University Press.

Coupland, N., \& Kristiansen, T. (2011). SLICE: Critical perspectives on language (de)standardisation. In T. Kristiansen \& N. Coupland (Eds.), Standard languages and language standards in a changing Europe (pp. 11-35). Oslo: Novus.

Darquennes, J., \& Vandenbussche, W. (Eds.). (2015). Die Standardisierung von Minderheitensprachen/ The standardisation of minority languages/La standardisation des langues minoritaires. Special issue of Sociolinguistica 29. Berlin/Boston: De Gruyter.

Davies, W. V., \& Langer, N. (2006). The making of bad language. Lay linguistic stigmatisations in German, past and present. Frankfurt: Peter Lang.

De Vogelaer, G., \& Seiler, G. (2012). The dialect laboratory: Introductory remarks. In G. De Vogelaer \& G. Seiler (Eds.), The Dialect Laboratory: Dialects as a testing ground for theories of language change (pp. 1-32). Amsterdam: John Benjamins.

Deumert, A., \& Vandenbussche, W. (Eds.). (2003a). Germanic standardizations. Past to present. Amsterdam: John Benjamins.

Deumert, A., \& Vandenbussche, W. (2003b). Standard languages: Taxonomies and histories. In A. Deumert \& W. Vandenbussche (Eds.), Germanic standardizations. Past to present (pp. 1-14). Amsterdam: John Benjamins.

Deumert, A., \& Vandenbussche, W. (2003c). Research directions in the study of language standardization. In A. Deumert \& W. Vandenbussche (Eds.), Germanic standardizations. Past to present (pp. 455-469). Amsterdam: John Benjamins.

Dossena, M. (2003). Scots. In A. Deumert \& W. Vandenbussche (Eds.), Germanic standardizations. Past to present (pp. 383-404). Amsterdam: John Benjamins.

Eckert, P. (2008). Variation and the indexical field. Journal of Sociolinguistics, 12(4), 453-476.

Elspaß, S. (2005). Sprachgeschichte von unten. Untersuchungen zum geschriebenen Alltagsdeutsch im 19. Jahrhundert. Tübingen: Niemeyer.

Elspaß, S. (2007). A twofold view 'from below'. New perspectives on language histories and language historiographies. Multilingua, 26(2/3), 3-9.

Elspaß, S. (2014). Prescriptive norms and norms of usage in nineteenth-century German. In G. Rutten, R. Vosters \& W. Vandenbussche (Eds.), Norms and usage in language history, 1600-1900. A sociolinguistic and comparative perspective (pp. 303-320). Amsterdam \& Philadelphia: Benjamins. 
Elspaß, S. (in press). Language standardization 'from below'. In W. Ayres-Bennett \& J. Bellamy (Eds.), Handbook of standardization and standard languages. Cambridge: Cambridge University Press.

Ferguson, C. A. (1959). Diglossia. Word, 15, 325-340.

Ferguson, C. (1962). The language factor in national development. Anthropological Linguistics, 4(1), 23-27.

Haugen, E. (1932). Ivar Aasen as a writer of Dano-Norwegian. Scandinavian Studies and Notes, 12(3), 53-59.

Haugen, E. (1933). The linguistic development of Ivar Aasen's New Norse. PMLA, 48(2), 558-597.

Haugen, E. (1934). Beginning Norwegian. A grammar and reader. Minneapolis, MN: Burgess (mimeograph). 2nd ed., New York: F. S. Crofts, 1937; 3rd ed., New York: Appleton-Century-Crofts, 1952.

Haugen, E. (1938). Phonological shifting in American Norwegian. Language, 14(2), 112-120.

Haugen, E. (1950a). Problems of bilingualism. Lingua, 2(3), 271-290.

Haugen, E. (1950b). The analysis of linguistic borrowing. Language, 26(2), 210-231.

Haugen, E. (1953). The Norwegian language in America. A study in bilingual behavior. Philadelphia: University of Pennsylvania Press.

Haugen, E. (1954). Review of Weinreich (1953). Language, 30, 380-388.

Haugen, E. (1962). Schizoglossia and the linguistic norm. Georgetown University Monograph Series on Languages and Linguistics, 15, 63-69.

Haugen, E. (1966a). Language conflict and language planning. The case of modern Norwegian. Cambridge, MA: Harvard University Press.

Haugen, E. (1966b). Dialect, language, nation. American Anthropologist, 68(4), 922-935.

Haugen, E. (1972). Language planning, theory and practice. In E. Haugen (Ed.), The ecology of language: Essays (pp. 287-295). Stanford: Stanford University Press.

Haugen, E. (1980). On the making of a linguist. In B. H. Davis \& R. O'Cain (Eds.), First person singular. Papers from the conference on an oral archive for the history of American linguistics (pp. 131-143). Amsterdam: John Benjamins.

Haugen, E. (1982). The implementation of corpus planning. Theory and practice. In J. Cobarrubias \& J. A. Fishman (Eds.), Progress in language planning: International perspectives (pp. 269-289). Berlin: De Gruyter.

Haugen, E. (1987). Blessings of Babel. Bilingualism and language planning. Problems and pleasures. Berlin: De Gruyter.

Havránek, B. (1932). Úkoly spisovného jazyka a jeho kultúra. In B. Havránek \& M. Weingart (Eds.), Spisovná čeština a jazyková kultúra (pp. 32-84). Prague: Melantrich.

Hickey, R. (2013). Supraregionalisation and dissociation. In J. K. Chambers \& N. Schilling (Eds.), Handbook of language variation and change (pp. 537-554). Amsterdam: Wiley-Blackwell.

Hornberger, N. H. (2006). Frameworks and models in language policy and planning. In T. Ricento (Ed.), An introduction to language policy. Theory and method (pp. 24-41). Malden, MA: Blackwell.

Hutton, C. M. (1999). Linguistics and the Third Reich. Mother-tongue fascism, race, and the science of language. London: Routledge.

Irvine, J. T., \& Gal, S. (2000). Language ideology and linguistic differentiation. In P. V. Kroskrity (Ed.), Regimes of language. Ideologies, polities, and identities (pp. 35-83). Santa Fe: School of American Research Press.

Jespersen, O. (1925). Mankind, nation, and individual from a linguistic point of view. Cambridge, MA: Harvard University Press.

Joseph, J. E. (1981). The standard language. Theory, dogma, and sociocultural reality. PhD thesis, The University of Michigan.

Joseph, J. E. (1987). Eloquence and power. The rise of language standards and standard languages. London: Frances Pinter.

Joseph, J. E. (2016). Divided allegiance. Martinet's preface to Weinreich's Languages in contact (1953). Historiographia Linguistica, 43(3), 343-362.

Joseph, J. E. (2018). Language, mind and body. A conceptual history. Cambridge: Cambridge University Press.

Joseph, J. E. (in press - a). Is/ought. Hume's guillotine, linguistics, and standards of language. In D. Chapman \& J.D. Rawlins (Eds.), Language Prescription. Values, ideologies and identity. Bristol: Multilingual Matters. 
Joseph, J.E. (in press - b). Identity construction. In M. Hundt, D. Perez, J. Kabatek \& D. Schreier (Eds.), English and Spanish in contact. World languages in interaction. Cambridge: Cambridge University Press.

Kloss, H. (1952). Die Entwicklung neuer germanischer Kultursprachen von 1800 bis 1950. Munich: Pohl. (2nd ed., Düsseldorf: Schwann, 1978).

Kloss, H. (1967). Abstand languages' and 'Ausbau languages. Anthropological Linguistics, 9(7), $29-41$.

Labov, W. (1963). The social motivation of a sound change. Word, 19(3), 273-309.

Lane, P., Costa, J., \& De Korne, H. (Eds.). (2018). Standardizing minority languages. Competing ideologies of authority and authenticity in the global periphery. New York/London: Routledge.

Langer, N. (2001). Linguistic purism in action. How auxiliary tun was stigmatized in Early New High German. Berlin/New York: Walter de Gruyter.

Langer, N. (2003). Low German. In A. Deumert \& W. Vandenbussche (Eds.), Germanic standardizations. Past to present (pp. 281-301). Amsterdam: John Benjamins.

Langer, N., \& Havinga, A. E. (2015). Invisible languages in historical sociolinguistics A conceptual outline, with examples from the German-Danish borderlands. In A. E. Havinga \& N. Langer (Eds.), Invisible languages in the nineteenth century (pp. 1-34). Oxford: Peter Lang.

Latour, B. (1991). Nous n'avons jamais été modernes. Essai d'anthropologie symétrique, Paris: La Découverte. (English version, We have never been modern, trans. by Catherine Porter, Cambridge, Mass.: Harvard University Press, 1993).

Lippi-Green, R. (2012 [1997]). English with an accent. Language, ideology, and discrimination in the United States. London: Routledge.

Martineau, F. (2013). Written documents: What they tell us about linguistic usage. In M. Van der Wal \& G. Rutten (Eds.), Touching the past. Studies in the historical sociolinguistics of ego-documents (pp. 129-148). Amsterdam: John Benjamins.

McColl Millar, R. (2005). Language, nation, and power. An introduction. Basingstoke: Palgrave Macmillan.

Milroy, J. (1992). Social network and prestige arguments in sociolinguistics. In K. Bolton \& H. Kwok (Eds.), Sociolinguistics today. International perspectives (pp. 146-162). London: Routledge.

Milroy, J. (2001). Language ideologies and the consequences of standardization. Journal of Sociolinguistics, 5(4), 530-555.

Milroy, J., \& Milroy, L. (1985). Authority in language. Investigating language prescription and standardisation. London: Routledge and Kegan Paul.

Mukařovský, J. (1932). Jazyk spisovný a jazyk básnický. In B. Havránek \& M. Weingart (Eds.), Spisovná čeština a jazyková kultúra (pp. 123-156). Prague: Melantrich.

Nevalainen, T., \& Raumolin-Brunberg, H. (2017). Historical sociolinguistics. Language change in Tudor and Stuart England (2nd ed.). London: Routledge.

Nevalainen, T., \& Rutten, G. (2012). Comparative historical sociolinguistics and the history of negation. Neuphilologische Mitteilungen, 2012(3), 261-273.

Poplack, S., Jarmasz, L.-G., Dion, N., \& Rosen, N. (2015). Searching for standard French: The construction and mining of the Recueil historique des grammaires du français. Journal of Historical Sociolinguistics, 1(1), 13-55.

Puttaert, J. (2016). Linguistic hybridity in nineteenth-century lower-Class letters. A case study from Bruges. In A.-C. Edlund, T. G. Ashplant, \& A. Kuismin (Eds.), Reading and writing from below. Exploring the margins of modernity (pp. 215-234). Umeå: Umeå University/Royal Skyttean Society.

Rutten, G. (2016). Historicizing diaglossia. Journal of Sociolinguistics, 20(1), 6-30.

Rutten, G., \& Van der Wal, M. (2014). Letters as Loot. A sociolinguistic approach to seventeenth-and eighteenth-century Dutch. Amsterdam/Philadelphia: John Benjamins.

Rutten, G., \& Vosters, R. (2020). Historische meertaligheid: nieuwe kansen voor de historische taalkunde. Taal en Tongval: Language Variation in the Low Countries, 71(2), 99-105.

Rutten, G., \& Vosters, R. (in press). Language standardization 'from above'. In W. Ayres-Bennett \& J. Bellamy (Eds.), Handbook of standardization and standard languages. Cambridge: Cambridge University Press.

Simley, A. (1930). A study of Norwegian dialect in Minnesota. American Speech, 5, 469-474.

Smakman, D. (2015). The westernising mechanisms in sociolinguistics. In D. Smakman \& P. Heinrich (Eds.), Globalising sociolinguistics Challenging and expanding theory (pp. 16-35). London: Routledge. 
Thomas, G. (1991). Linguistic purism. London: Longman.

Tieken-Boon van Ostade, I. M., \& Nevalainen, T. (2006). Standardisation. In R. Hogg \& D. Denison (Eds.), A History of the English Language (pp. 271-311). Cambridge: Cambridge University Press.

Turner, J. (2014). Philology. The forgotten origins of the modern humanities. Princeton NJ: Princeton University Press.

Tuten, D. N. (2003). Koineization in Medieval Spanish. Berlin: De Gruyter.

van der Wal, M. (2007). Eighteenth-century linguistic variation from the perspective of a Dutch diary and a collection of private letters. In S. Elspaß, N. Langer, J. Scharloth, \& W. Vandenbussche (Eds.), Germanic language histories 'from below' (1700-2000) (pp. 83-98). Berlin/New York: De Gruyter.

Voeste, A. (2007). Traveling through the lexicon. 'Self-organized' spelling changes. Written Language \& Literacy, 10(2), 89-102.

Weinreich, U. (1951). Research problems in bilingualism with special reference to Switzerland. PhD thesis, Columbia University. [Published as Weinreich (2011)].

Weinreich, U. (1953). Languages in contact. Findings and problems Preface by André Martinet. New York: Publications of the Linguistic Circle of New York.

Weinreich, U. (1954). Is a structural dialectology possible? Word, 10, 388-400.

Weinreich, U. (2011). Languages in contact. French, German, and Romansh in twentieth-century Switzerland. Introduction and notes by Ronald I. Kim \& William Labov. Amsterdam: John Benjamins.

Publisher's Note Springer Nature remains neutral with regard to jurisdictional claims in published maps and institutional affiliations.

John E. Joseph is professor of applied linguistics in the University of Edinburgh. He received his $\mathrm{PhD}$ from the University of Michigan for his dissertation on The Standard Language: Theory, Dogma and Sociocultural Reality (1981). His books include Eloquence and Power (Blackwell, 1987), Language and Identity (Palgrave Macmillan 2004), Language and Politics (Edinburgh University Press, 2006), Saussure (Oxford University Press, 2012) and Language, Mind and Body (Cambridge University Press, 2018).

Gijsbert Rutten is a senior researcher in historical sociolinguistics and an associate professor in Dutch historical linguistics at the Leiden University Centre for Linguistics. His latest book is Language Planning as Nation Building. Ideology, policy and implementation in the Netherlands, 1750-1850 (Benjamins, 2019). He currently leads a research project on Dutch-French language contact between 1500 and 1900 .

Rik Vosters teaches Dutch linguistics and historical sociolinguistics at Vrije Universiteit Brussel. He leads several projects dealing with the social history of Early and Late Modern Dutch, and coordinates the Historical Sociolinguistics Research and Training Platform. His research interests include language history from below, norms and usage, language contact, and language policy and planning. 